\title{
UDC 658.52.011.56
}

\section{ANALYTICAL APPROACH TO DETERMINATION OF SURFACE STRENGTHENING OF CHEVRON GEARS}

\author{
Kateryna Kamchatna-Stepanova \\ National Technical University «Kharkiv Polytechnic Institute», \\ Kharkiv, Ukraine
}

\begin{abstract}
Summary. The construction of an information model of the processes of gear processing of hardened large-modular chevron gears is one of the stages of control of the technological structure and parameters of the automation of the design of the technological process. Taking into account the principles of information classification, the automated gear processing process is considered as a control object, consisting of a number of technological objects: initial material (input of the control object); environment (process conditions); gear wheel (output of the control object, quantitative and qualitative characteristics of the surface layer) The construction of an information model of the processes of gear processing of hardened large-modular chevron gears is one of the stages of control of the technological structure and parameters of the automation of the design of the technological process.
\end{abstract}

Key words: milling cutter, chevron gears of wheels, information model, parameters, gear processing, design automation, optimal control, surface layer quality.

Statement of the problem. Methods of forming of chevron gears that affect the depth and degree of strengthening of the surface layer largely depends on a number of factors, such as elements of cutting conditions, geometric parameters of the tool and condition of the cutting blade of the milling cutter tooth, properties of the tool and the processed materials, type of cutting fluid, and the cooling scheme.

Analysis of available research. In the design of a milling cutter on the processed tooth surface of finishing gear hobs, the productivity was tried to achieve in the following way: by increasing of cutting speed and increasing of tool feed.

Objective of the investigation is to consider and analyse the analytical approach to determination of the surface strengthening of gear wheels adn to investigate the influence of technological factors on quality parameters of involute surfaces of cylindrical chevron gears.

Statement of the task. Force and temperature factors will influence the degree of the strengthening of cylindrical chevron gears (figure 1) in all methods of their mechanical processing.

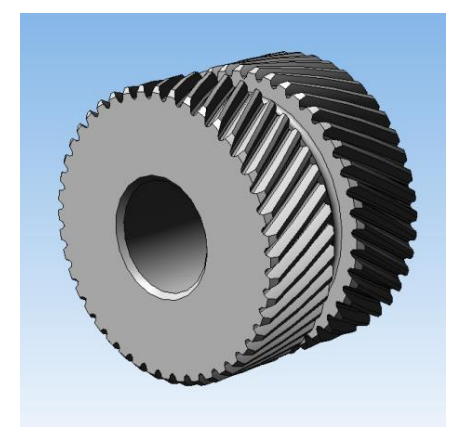

Figure 1. Cylindrical chevron gear 
Considering that almost all tools (milling cutters equipped with cemented carbide and mineral-ceramic cutting inserts, rollers) used in machine processing have a rounded working section with a given radius value, to determine the strengthening of the surface layer from the force factor we simulate the working section of milling cutter with a spherical indenter $[1,2$, 4]. When a spherical indenter indents the surface of the material, the force acting on it is related to the indentation diameter:

$$
P=m d_{0}^{n}
$$

where $d_{0}$ is the diameter of the indentation; $m$ and $n$ are coefficients depending on the material properties. we obtain:

By calculating the diameter of the indentation through the area of the plastic indentation

$$
P=m{\frac{4 A_{r}}{\pi}}^{n / 2}
$$

Deformation forces according to the developed theory of contact interaction:

$$
P=m{\frac{4 A_{r}}{\pi}}^{n / 2}
$$

Substituting (2) into (3), we obtain the equation for the degree of strengthening

$$
k=\frac{m}{0,6 c^{\prime} \sigma_{T}}\left(\frac{4}{\pi}\right)^{n / 2} A_{r}^{(n / 2-1)}
$$

where 0,6 is a coefficient that takes into account transition of plastic deformation on the basis of roughness protrusion.

Thus, (4) is a starting point for calculating the degree of strengthening during gear milling without taking into account temperature changes $[4,5,6,8,12]$.

In each case the area $A_{r}$ is determined by processing conditions. The coefficients $m$ and $n$ are determined by Rockwell hardness tests (HRC) at different loads. Thus, for some materials the values of these coefficients are given below:

$\begin{array}{ccccccccc}\text { Steel grade: } & 40 & 45 & 40 \mathrm{Cr} & 18 \mathrm{CrNi3} & 34 \mathrm{CrMo} & 3 \mathrm{Cr} 13 & \mathrm{Cr} 18 \mathrm{Ni} 9 \mathrm{Mn} & \text { 38Cr1Ni } \\ m & 44 & 56 & 63 & 135 & 75 & 61 & 40 & 63 \\ n & 2,32 & 2,31 & 2,32 & 2,31 & 2,29 & 2,31 & 2,26 & 2,32 /\end{array}$

During gear milling, the contact area of the cutter with the processed spur gear that determines the degree of strengthening:

$$
A_{r}=\left[\arccos \left(1-\frac{\Delta h}{\rho}\right)+h_{3} \frac{\Delta h_{\mathrm{y \Pi}}}{\sin \alpha}\right] \times\left[\frac{t-R_{z}}{\sin \varphi}+4 \arccos \left(1-\frac{R_{z}}{r}\right)\right]
$$

where $\Delta h$ is the elastic-plastic layer of the processed material; $h_{3}$ is the wear on the rear surface of the cutter; $\Delta h_{y}$ is the value of elastic recovery, calculated by the formula

$$
\Delta h_{\mathrm{y}}=2,4\left(1-\mu^{2}\right)\left(\frac{H B}{E}\right)^{2} \text {. }
$$


Substituting (5) into (6), we obtain the equation for calculating the area of actual contact of the tool with the workpiece during gear milling:

$$
\begin{aligned}
& A_{r}=[\arccos \left.\left(0,5-\frac{2 \tau_{0}}{\sigma_{T}}\right)+h_{3}+\frac{2,4 \rho\left(1-\mu^{2}\right)}{\sin \alpha}\left(\frac{H B}{E}\right)^{2}\right] \times \\
& \times\left[\frac{t-R_{Z}}{\sin \varphi}+4 \arccos \left(1-\frac{R_{z}}{\rho}\right)\right] .
\end{aligned}
$$

In the process of high-speed gear milling the contact area of the cutter with the workpiece:

$$
\begin{gathered}
A_{r}=\left[\arccos \left(0,5-\frac{2 \tau_{0}}{\sigma_{T}}\right)+\frac{\pi \rho \arccos \left[1-24\left(1-\mu^{2}\right)\left(\frac{H B}{E}\right)^{2}\right]}{90}\right] \times \\
\times \frac{\pi \rho \arccos \left(1-\frac{R_{z}}{\rho}\right)}{90}
\end{gathered}
$$

During SPD processing the actual contact area of the tool with the workpiece:

$$
A_{r}=\pi R \frac{t_{m 0} 0}{100}\left(\frac{h_{p l}}{R_{p 0}}\right)^{v_{0}} \times \times\left\{h_{\mathrm{K}} \frac{180-\arccos \frac{s-a_{p l}}{a_{p l}}}{180}+h_{y}\left[1-\frac{180-\arccos \frac{s-a_{p l}}{a_{p l}}}{180}\right]\right\} .
$$

Substituting (7) into (9), we obtain the equation for calculating the degree of strengthening at blade gear processing from the force factor:

$$
k=\frac{m}{0,6 c^{\prime} \sigma_{T}}\left(\frac{4}{\pi}\right)^{n / 2}\left\{\begin{array}{c}
\left.\left[\arccos \left(0,5-\frac{2 \tau_{0}}{\sigma_{T}}\right)+h_{3}+\frac{2,4 \rho\left(1-\mu^{2}\right)}{\sin \alpha}\left(\frac{H B}{E}\right)^{2}\right] \times\right]^{\left(n / 2^{-1}\right)} \\
\times\left[\frac{t-R_{z}}{\sin \varphi}+4 \arccos \left(1-\frac{R_{z}}{\rho}\right)\right]
\end{array},\right.
$$

To calculate the degree of strengthening at high-speed gear milling:

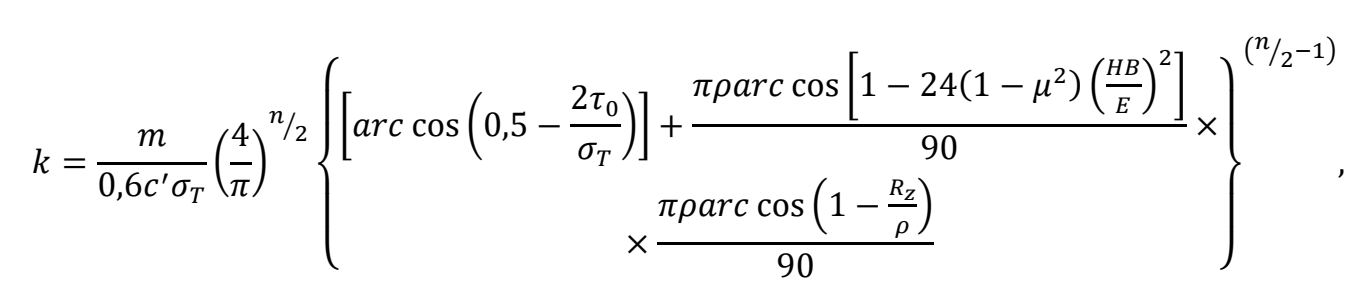

Interaction of surface parameters of cylindrical chevron gears with the conditions of their machining with cutters equipped with cemented carbide inserts $[3,6,7]$ is shown in table 1 , influence of technological factors on quality parameters of involute surfaces of cylindrical chevron gears at high-speed gear milling with cutters equipped with mineral-ceramic cutting inserts is shown in table 2. 


\section{Table 1}

Interaction of surface parameters of cylindrical chevron gears with the conditions of their processing with cutters equipped with cemented carbide inserts

\begin{tabular}{|c|c|c|c|c|c|c|c|c|c|c|c|c|c|c|c|c|}
\hline \multirow{3}{*}{$\begin{array}{l}\text { Machining } \\
\text { conditions }\end{array}$} & \multicolumn{12}{|c|}{ Geometric characteristics of machined surface } & \multirow{2}{*}{\multicolumn{4}{|c|}{$\begin{array}{c}\text { Parameters of } \\
\text { physical and } \\
\text { mechanical } \\
\text { properties of the } \\
\text { surface layer }\end{array}$}} \\
\hline & \multicolumn{7}{|c|}{ Roughness parameters } & \multicolumn{3}{|c|}{$\begin{array}{c}\text { Ripple } \\
\text { parameters }\end{array}$} & \multicolumn{2}{|c|}{$\begin{array}{c}\text { Microdeviation } \\
\text { parameters }\end{array}$} & & & & \\
\hline & $R a$ & $R z$ & Rmax & $S m$ & $S$ & $t p$ & $R p$ & $W z$ & $W m$ & Smw & $\operatorname{Hmax}$ & $H p$ & $H \mu 0$ & $h \mu$ & $\sigma 0$ & $h \sigma$ \\
\hline $\begin{array}{l}\text { Feed } \mathrm{S}, \\
\mathrm{mm} / \mathrm{min} \\
\quad<50 \\
\quad \geq 50\end{array}$ & $\begin{array}{l}0 \\
+ \\
*\end{array}$ & $\begin{array}{c}0 \\
+*\end{array}$ & $\begin{array}{c}0 \\
+^{*}\end{array}$ & $\begin{array}{l}+^{*} \\
+^{*}\end{array}$ & $\begin{array}{l}+^{*} \\
+^{*}\end{array}$ & $\begin{array}{l}0 \\
0\end{array}$ & $\begin{array}{l}- \\
+ \\
+\end{array}$ & $\begin{array}{c}0 \\
+*\end{array}$ & $\begin{array}{c}0 \\
+^{*}\end{array}$ & $\begin{array}{c}0 \\
+^{*}\end{array}$ & $\begin{array}{c}0 \\
+^{*}\end{array}$ & $\begin{array}{c}0 \\
+^{*}\end{array}$ & $\begin{array}{c}+ \\
-*\end{array}$ & $\begin{array}{c}+ \\
+*\end{array}$ & $\begin{array}{l}+ \\
-*\end{array}$ & $\begin{array}{c}+ \\
+*\end{array}$ \\
\hline $\begin{array}{c}\text { Cutting speed } \\
\qquad, \mathrm{m} / \mathrm{s} \\
<0,80 \\
\geq 0,80\end{array}$ & $\begin{array}{l}+ \\
* \\
-*\end{array}$ & $\begin{array}{l}+^{*} \\
-*\end{array}$ & $-*$ & $\begin{array}{l}+ \\
-*\end{array}$ & $\begin{array}{l}+ \\
-*\end{array}$ & - & $\begin{array}{l}+ \\
* \\
-*\end{array}$ & $\begin{array}{l}+^{*} \\
-*\end{array}$ & $-*$ & $\begin{array}{l}-* \\
+\end{array}$ & $\begin{array}{l}- \\
+\end{array}$ & $\begin{array}{l}-* \\
+\end{array}$ & $\begin{array}{l}-* \\
+\end{array}$ & $\begin{array}{c}+ \\
+*\end{array}$ & $\begin{array}{c}+ \\
+^{*}\end{array}$ & $\begin{array}{c}+ \\
+*\end{array}$ \\
\hline Cutting depth $t$ & & & $+*$ & & & + & & & $+*$ & $+*$ & $+*$ & $+*$ & $+*$ & & & \\
\hline $\begin{array}{l}\text { Rake angle of } \\
\text { the cutter } \\
>0 \\
<0\end{array}$ & $\begin{array}{l}- \\
+ \\
*\end{array}$ & $+^{-}$ & & - & $+^{*}$ & 0 & $\begin{array}{l}+ \\
* \\
+ \\
*\end{array}$ & $\begin{array}{l}+^{*} \\
+^{*}\end{array}$ & $+*$ & $+*$ & + & & & $t^{*}$ & $+*$ & $+^{*}$ \\
\hline $\begin{array}{c}\text { Radius of } \\
\text { rounding of } \\
\text { cutting edge, } \rho\end{array}$ & & & $+^{*}$ & & & + & & & & & & & $+*$ & & & \\
\hline $\begin{array}{c}\text { Roughness of } \\
\text { cutting edge, } \\
R_{\text {zркр }}\end{array}$ & & & - & & & 0 & & & + & + & $+^{*}$ & + & + & + & + & + \\
\hline $\begin{array}{l}\text { Stiffness of } \\
\text { the system } \\
\text { DTMS }\end{array}$ & $\begin{array}{l}+ \\
*\end{array}$ & $+*$ & + & $+^{*}$ & + & 0 & + & + & 0 & 0 & +0 & + & 0 & 0 & 0 & 0 \\
\hline
\end{tabular}

Notes:

1. Symbol « $\langle\gg$ means that an increase (or decrease) in a specified machining condition contributes to an increase or decrease of a certain parameter of surface quality.

2. Symbol «-» sign means that an increase (or decrease) in a specified processing condition contributes to a decrease or increase of a certain parameter of surface quality.

3. Symbol «0» sign means that a change in a specified machining condition has no effect on a certain parameter of surface quality.

4. Symbol $«^{*} »$ denotes machining conditions which have a major impact on certain parameter of surface quality. 
Table 2

Influence of technological factors on quality parameters of involute surfaces of cylindrical chevron gears at highspeed gear milling with cutters equipped with mineral-ceramic cutting inserts

\begin{tabular}{|c|c|c|c|c|c|c|c|c|c|c|c|c|c|c|c|c|}
\hline \multirow{3}{*}{$\begin{array}{l}\text { Machining } \\
\text { conditions }\end{array}$} & \multicolumn{12}{|c|}{ Geometric characteristics of machined surface } & \multirow{2}{*}{\multicolumn{4}{|c|}{$\begin{array}{l}\text { Parameters of } \\
\text { physical and } \\
\text { mechanical } \\
\text { properties of the } \\
\text { surface layer }\end{array}$}} \\
\hline & \multicolumn{6}{|c|}{ Roughness parameters } & \multicolumn{4}{|c|}{$\begin{array}{c}\text { Ripple } \\
\text { parameters }\end{array}$} & \multicolumn{2}{|c|}{$\begin{array}{l}\text { Microdeviation } \\
\text { parameters }\end{array}$} & & & & \\
\hline & $R a$ & $R z$ & $\operatorname{Rmax}$ & $S m$ & $S$ & $t p$ & $R p$ & $W z$ & $W m$ & $S m w$ & $\operatorname{Hmax}$ & $H p$ & $\mathrm{H \mu O}$ & $h \mu$ & $\sigma 0$ & $h \sigma$ \\
\hline Feed $\underset{\text { Smin }}{\text { per minute, }}$ & $+*$ & + & + & + & + & 0 & + & + & + & + & + & + & + & + & + & + \\
\hline Feed per revolution & $+*$ & $+*$ & $+*$ & $+*$ & $+*$ & 0 & $+*$ & + & + & + & + & + & + & + & + & + \\
\hline Feed per hob tooth & $+^{*}$ & $+*$ & $+^{*}$ & + & + & 0 & $+*$ & $+^{*}$ & $+^{*}$ & $+*$ & $+^{*}$ & $+^{*}$ & $+^{*}$ & $+^{*}$ & + & + \\
\hline Cutup milling & $+*$ & * & $+*$ & $+*$ & $+*$ & + & $+^{*}$ & $+^{*}$ & $+^{*}$ & $+*$ & $+*$ & $+^{*}$ & & 0 & $+*$ & $+{ }^{+*}$ \\
\hline Cutdown milling & - & - & - & 0 & 0 & & $+*$ & $+*$ & $+^{*}$ & $+^{*}$ & + & + & 0 & 0 & 0 & 0 \\
\hline $\begin{array}{l}\text { Stiffness of the } \\
\text { system } \\
\text { DTMS }\end{array}$ & - & - & - & & & 0 & - & $+*$ & -* & 0 & -* & -* & -* & -* & -* & -* \\
\hline $\begin{array}{l}\text { Yield strength of } \\
\text { work material, } \\
\sigma_{m}\end{array}$ & - & - & - & - & - & 0 & - & + & + & + & + & + & $+^{*}$ & $+^{*}$ & +* & $+*$ \\
\hline $\begin{array}{c}\text { Original ripple, } \\
W_{z_{o}}\end{array}$ & $+*$ & $+^{*}$ & $+^{*}$ & $+*$ & $+^{*}$ & - & $+*$ & 0 & 0 & 0 & 0 & $+^{*}$ & $+^{*}$ & $+^{*}$ & $+*$ & $+*$ \\
\hline $\begin{array}{c}\text { Original } \\
\text { macrodeviation, } \\
\operatorname{Hmax}_{0}\end{array}$ & 0 & 0 & 0 & 0 & 0 & & & & & & & & + & + & & \\
\hline $\begin{array}{c}\text { Original } \\
\text { roughness, } \\
R z_{0} \\
\end{array}$ & 0 & 0 & 0 & 0 & 0 & 0 & 0 & + & + & + & 0 & 0 & 0 & 0 & + & + \\
\hline
\end{tabular}

The reason for the deformation of the surface layer (and therefore the strengthening) is that metal cutting is carried out with the milling cutter tooth with a radius of rounding of the cutting edge $\rho$ and partial elastic recovery of the uncut deformed metal.

Thus, for milling cutters with micrometric adjustment on front and rear surfaces, sharpened with diamond wheel, the radius of rounding of cutting edge of milling cutter teeth $\rho=3 \ldots 10 \mu \mathrm{m}$, for module gear hobs made from high-speed steel P6M5, with wear on the back surface $0,1 \ldots 0,3 \mathrm{~mm}$ the radius of rounding of cutting edge of milling cutter teeth $\rho=20 \ldots 60 \mu \mathrm{m}$; for modular cemented carbide hobs T15K6, BK10 the radius of rounding of cutting edge of milling cutter teeth $\rho=80 \ldots 450$ microns.

The considered factors that influence the deformation of the surface layer are manifested depending on cutting modes, grade of machines and tool materials, tool geometry etc [10].

Thus, metal, that forms the surface layer in the process of cutting, undergoes repeated plastic deformation. This, in turn, changes all physical and chemical properties and structure of the metal. According to dislocation theory, the strengthening of the metal in the process of work 
hardening is the concentration of dislocations at the shear lines. Atomic layers at the location of dislocations are elastically distorted in such a way that a local stress concentrator occurs. During plastic deformation the number of dislocations in the metal can increase by several orders of magnitude. In undeformed metal the average dislocation density $j=10^{6}-10^{8} \mathrm{~cm}^{2}$, but in hardened metal it increases to $j=10^{14} \mathrm{~cm}^{2}$. During plastic deformation the strengthening of a metal occurs due to increase of density of dislocations and interaction of their force fields $[3,6]$.

The degree of strengthening is characterised by the depth of the plastically deformed surface layer $h_{c}$ and the degree of work hardening $N$, that is determined by the formula:

$$
N=\frac{H_{1}-H}{H} \cdot 100 \% \text {, }
$$

where $H_{l}$ is the microhardness of the part directly from the surface; $H$ is the microhardness of the surface layer at depth of $h_{c} . i$. According to the changes that occur in a surface layer, the depth of the hardened layer is determined either by the change of microhardness along in a cross section or by the change of character of interference lines on radiograph during layer-bylayer etching of the examined surface [11].

Applied to cutup gear milling the formula for determining the depth of the hardened layer is as follows:

$$
h_{c}=\frac{1-\sin \beta}{2 \sin \beta} \cdot \sin \Psi \text { ск, }
$$

where $\Psi_{c K}$ is the sliding angle.

The shear angle $\beta$ is calculated using the formula:

$$
\operatorname{tg} \beta=\frac{\cos \gamma}{\xi-\sin \gamma} \cdot \sin \Psi_{\mathrm{c \kappa}}
$$

where $\xi$ is the chip shrinkage; $\gamma$ is the rake angle of the cutter.

The formula (15) is valid when the ratio of depth of relative penetration resulting in cutting without lubrication is $a_{i} / \rho \geq 0,5$, and with lubrication, $a_{i} / \rho \geq 0,31$. The thickness of the cut layer $a_{i}=S_{z} \cdot \sin \Psi_{c k} \cdot \sin \varphi$.

Technological factors that affect the depth and degree of strengthening of the surface layer largely depend on a number of factors, such as elements of cutting mode, geometric parameters of the tool and condition of the cutting blade of the milling cutter tooth, properties of the tool and the processed materials, type of cutting fluid, and the cooling scheme, etc.

The cutting speed is a factor that determines the rate of plastic deformation of the surface layer. With increasing strain rate the tensile strength and yield strength of structural materials increase $[7,9]$. The increase of the yield stress reduces the plasticity of the processed material and acts in the direction of decreasing the degree of strengthening.

The cutting speed determines the duration of the contact between the rear surface of the cutter and the workpiece. During higher cutting speed, the surface of the part passes through the contact zone without getting the degree of strengthening that it could have got at a lower cutting speed and longer contact time.

When the cutting speed increases to a certain value, the plastic zone narrows and the depth of its spreading decreases below the shear line. The first and the second decrease the degree of strengthening.

The cutting speed, as a temperature factor, changes the degree of development of the built up edge in gear milling with modular gear milling cutters made of high-speed steel P6M5 
and it changes the nature of flow and bypass of metal from the zone of chip formation towards the rear face. The degree of sharpening increases the effective radius rounding of the cutting edge and thus it increases the work hardening.

The cutting speed affects the change of the intensity of softening process [3, 6]. During plastic deformation in the surface layers of the metal two processes occur simultaneously: strengthening and softening. When the temperature and the degree of deformation increase, the speed of the process of softening, that occurs due to the recrystallization, increases. Increasing the temperature of the cutting improves the intensity of the process of softening and reduces the degree of strengthening.

During cutup gear milling at the sliding angle of the cutter $\Psi_{\text {ск }}$ the increase of contact temperature to the temperature corresponding to the maximum embrittlement will reduce the degree of strengthening, and the further increase of temperature should increase the work hardening, because in this case the flexibility increases.

Conclusions. The results of analytical studies of forming parameters of condition of the surface layer of cylindrical gears during gear milling, high-speed gear milling and PSD with thread tapered rolls, their mathematical description and experimental testing allow to establish the interaction between the parameters of the condition of the surface layer of cylindrical gears that determine the operational properties with the conditions of their processing. Scientifically substantiated approach to the formation of parameters of the parameters of condition of the surface layer of cylindrical gears during gear milling, high-speed gear milling and PSD with thread tapered rolls allows to manage the parameters of the state of the surface layer, depending on the type of processing.

\section{References}

1. Yampolsky L. S., Polishchuk M. N. Optimizatsiya tekhnologicheskikh protsessov v gibkikh proizvodstvennykh sistemakh. K.: Tekhnika, 1988. $175 \mathrm{p}$.

2. Tekhnologiya proizvodstva i metody metody obespecheniya kachestvashevronnykh zubchatykh koles i peredach / pod obshch. red. V. Ye. Starzhinskogo, M. M Kane. S-Pb.: Professiya, 2007. 832 p.

3. Kravtsov N. V., Timofeyev YU. V., Klochko A. A. i dr. Tekhnologicheskiye osobennosti obrabotki krupnomodul'nykh zakalennykhshevronnykh zubchatykh koles / nauch. red.. A. A. Permyakov. VolGTU Tol'yatti: ZAO "ONIKS", 2012. 254 p., il., tabl.; (Seriya: Upravleniye kachestvom tekhnologicheskikh protsessov v mashinostroyenii / obshch. red. YU. M. Solomentsev).

4. Kane M. M., Suslov A. G., Gorlenko O. A. i dr. Upravleniye kachestvom produktsii mashinostroyeniya / pod obshch. red. d.t.n. M. M. Kane. M: Mashinostroyeniye, 2010. 416 p.

5. Hasanov M. I., Klochko O. O., Shelkovyy O. M., Klymenko H. P. Kompleksni parametry otsinky stanu poverkhon' vidnovlenykh krupnomodul'nykh zubchastykh kolis. Vazhke mashynobuduvannya. Problemy ta perspektyvy rozvytku. Materialy XIX Mizhnarodnoyi naukovo-tekhnichnoyi konferentsiyi 01-04 chervnya 2021 roku / za zah. red. V. D. Koval'ova. Kramators'k: DDMA, 2021. P. 34-35.

6. Klochko A. A., Zakovorotnyy A. Y., Antsyferova O. A., Kamchatnaya-Stepanova E. V. Analyz sovremennykh konstruktsyy ynstrumentov dlya narezanyya krupnomodul'nykh shevronnykh koles. Vazhke mashynobuduvannya. Problemy ta perspektyvy rozvytku. Materialy XIX Mizhnarodnoyi naukovotekhnichnoyi konferentsiyi 01-04 chervnya 2021 roku / za zah. red. V. D. Koval'ova. Kramators'k: DDMA, 2021. P. 68-70.

\section{Список використаної літератури}

1. Ямпольский Л. С., Полищук М. Н. Оптимизация технологических процессов в гибких производственных системах. К.:Техника, 1988. 175 с.

2. Технология производства и методы методы обеспечения качествашевронных зубчатых колес и передач / под общ. ред. В. Е. Старжинского, М. М Кане. С-Пб. Профессия, 2007. 832 с.

3. Кравцов Н. В., Тимофеев Ю. В., Клочко А. А. и др. Технологические особенности обработки крупномодульных закаленныхшевронных зубчатых колес / науч. ред.. А. А. Пермяков. ВолГТУ Тольятти: ЗАО «ОНИКС», 2012. 254 с. (Серия: Управление качеством технологических процессов в машиностроении / общ. ред. Ю. М. Соломенцев)

4. Кане М. М., Суслов А. Г., Горленко О. А. и др Управление качеством продукции машиностроения / под общ. ред. д.т.н. М. М. Кане. М: Машиностроение, 2010. 416 с. 
5. Гасанов М. І., Клочко О. О., Шелковий О. М., Клименко Г. П. Комплексні параметри оцінки стану поверхонь відновлених крупномодульних зубчастих коліс. Важке машинобудування. Проблеми та перспективи розвитку. Матеріали ХІХ Міжнародної науково-технічної конференції 01-04 червня 2021 року / за заг. ред. В. Д. Ковальова. Краматорськ: ДДМА, 2021. С. 34-35

6. Клочко А. А., Заковоротный А. Ю., Анцыферова О. А., Камчатная-Степанова Е. В. Анализ современных конструкций инструментов для нарезания крупномодульних шевронных колес. Важке машинобудування. Проблеми та перспективи розвитку. Матеріали ХІХ Міжнародної науковотехнічної конференції 01-04 червня 2021 року / за заг. ред. В. Д. Ковальова. Краматорськ: ДДМА, 2021. C. $68-70$.

\title{
УДК 658.52.011.56
}

\section{АНАЛІТИЧНИЙ ПІДХІД ВИЗНАЧЕННЯ ПОВЕРХНЕВОГО ЗМІЦНЕННЯ ШЕВРОННИХ ЗУБЧАСТИХ КОЛІС}

\author{
Катерина Камчатна-Степанова
}

\author{
Наџіональний технічний університет «Харківський політехнічний \\ інститут», Харків, Украӥна
}

\begin{abstract}
Резюме. Виробництво великомодульних шевронних зубчастих коліс є однією з найскладніших сфер важкого машинобудування $і$ за своїми якісними характеристикам поступається виробництву мало- та середньомодульних коліс Одне з головних завдань станкобудування є підвищення якості продукції, щзо випускається, в тому числі крупномодульних зубчастих передач важких металорізальних верстатів, прокатних станів, рудорозмельних млинів, крокуючих екскаваторів, підйомних машин, бурової техніки. Побудова інформаційної моделі прочесів зубооброблення загартованих крупномодульних зубчатих коліс $\epsilon$ одним із етапів управління технологічною структурою та параметрами автоматизачії проектування технологічного процесу. 3 урахуванням принципів класифікації інформації процес зубооброблення, щзо автоматизується, розглядається як об'єкт управління, щуо складається з ряду технологічних об'єктів: вихідний матеріал (вхід об'єкта управління, кількісна і якісна характеристики поверхневого шару); модуль обробки з системою управління й технологічним оснащенням (власне об'єкт управління). Завдання оптимального управління зубообробленням формулюється як завдання вибору формоутворення, який забезпечує максимальну продуктивність із забезпеченням якісного поверхневого шару загартованих зубчастих коліс при заданій точності з урахуванням показника собівартості. Шевронні зубчасті колеса сприймають значні реверсні навантаження, коли працюють в умовах високого контактного впливу. В умовах обробки великомодульних шевронних зубчастих коліс, де діють сили різання, жорсткість недостатня, величезний вплив має вибір технологічних факторів оброблення на розмір хвилястості.

Ключові слова: інформачійна модель, параметри, зубооброблення, автоматизація проектування, оптимальне управління, якість поверхневого шару.
\end{abstract}

